SAKAI SAMBAYAN — Jurnal Pengabdian kepada Masyarakat

\title{
PENINGKATAN KAPASITAS SASARAN PELAKSANA PROGRAM PERSIAPAN PERSALINAN DAN PENCEGAHAN KOMPLIKASI (P4K) DALAM PELAKSANAAN STRATEGI UNTUK MENGURANGI ANGKA KEMATIAN IBU (AKI) DI KECAMATAN PANJANG KOTA BANDAR LAMPUNG
}

\author{
Devi Yulianti ${ }^{1}$, Dian Kagungan ${ }^{2}$ \\ Jurusan Administrasi Publik Universitas Lampung, Bandar Lampung \\ Jl. Prof. Sumantri Brojonegoro No.1 Bandar Lampung 35145 \\ Penulis Korespodensi : devi.yulianti@fisip.unila.ac.id
}

\begin{abstract}
Abstrak
Tujuan umum yang dicapai dalam kegiatan ini adalah untuk menyebarluaskan hasil-hasil penelitian/kajian kepada masyarakat sebagai bagian dari upaya utuk memberdayakan dan meningkatkan kesejahteraan masyarakat, membangun kerjasama dan kemitraan dengan masyarakat sebagai perwujudan dan pengembangan kompetensi sosial di kalangan para dosen. Sedangakan tujuan khususnya adalah meningkatkan kapasitas sasaran pelaksanaan P4K di Puskesmas Kecamatan Panjang Kota Bandar Lampung dalam mengurangi AKI. Pelaksanaan kegiatan menggunakan metode ceramah dan diskusi. khalayak sasaran kegiatan seminar tentang peningkatan kapasitas sasaran pelaksana untuk menjalankan P4K adalah penanggung jawab dan pengelola program KIA Provinsi dan Kabupaten/Kota, bidan koordinator, kepala puskesmas, dokter, perawat, bidan, kader, forum peduli KIA (forum P4KI pokja posyandu, dll). Lokasi kegiatan pengabdian ini adalah di Puskesmas Kecamatan Panjang Kota Bandar Lampung. Hasil kegiatan pengabdian membawa peningkatan kemampuan dasar peserta. Peningkatan terendah sebesar $10 \%$ dan peningkatan tertinggi sebesar 20\%. Rata-rata peningkatan adalah sebesar 14,8\%. Berdasarkan hasil dan evaluasi pelaksanaan pengabdian kepada masyarakat dapat disimpulkan beberapa hal sebagai berikut: 1). Kemampuan peserta pelatihan pada aspek kognetif dan afektif mengalami peningkatan dengan rata-rata sebesar 14,8\%., 2).Hasil evaluasi menunjukan peserta memiliki persepsi positif dan motivasi yang tinggi untuk menjalankan point penting dalam pelatihan untuk membenahi metode dan proses pelaksanaan strategi untuk mengurangi angka kematian ibu, 3).Peserta menghendaki adanya pelatihan lanjutan.
\end{abstract}

Kata kunci : Peningkatan Kapasitas, Program Perencanaan Persalinan dan Pencegahan Komplikasi (P4K), Pelaksanaan Strategi

\section{Pendahuluan}

Pembangunan era millenium yang sudah di deklaraasikan, dikenal dengan millennium development goals (MDGs), dan deklarasi MDGs merupakan hasil perjuangan dan kesepakatan bersama antara negara-negara berkembang dan negara maju. Negara-negara berkembang berkewajiban untuk melaksanakannya, termasuk salah satunya Indonesia di mana kegiatan MDG's di Indonesia mencakup pelaksanaan kegiatan monitoring MDG's. Sedangkan negara-negara maju berkewajiban mendukung dan memberikan bantuan terhadap upaya keberhasilan setiap tujuan dan target MDG's. Secara nasional, komitmen tersebut dituangkan dalam berbagai dokumen perencanaan nasional, antara lain dalam Rencana Pembangunan Jangka Menengah Nasional (RPJMN) 2004-2009. Lalu, dipertegas pada RPJMN 2010-2014 dan Inpres No 3 Tahun 2010 tentang Program Pembangunan Berkeadilan.

Pemerintah telah memberi perhatian terhadap pencapaian delapan tujuan MDG's. Setiap tujuan MDGs menetapkan satu atau lebih target, serta masing-masing indikator akan diukur tingkat 
SAKAI SAMBAYAN — Jurnal Pengabdian kepada Masyarakat

pencapaiannya atau kemajuannya hingga tahun 2015. Secara global, ditetapkan 18 target dan 48 indikator. Namun, implementasinya tergantung pada setiap negara disesuaikan dengan kebutuhan pembangunan dan ketersediaan data yang digunakan untuk mengatur tingkat kemajuannya. Indikator global tersebut bersifat fleksibel bagi setiap negara. Keseriusan itu diimplementasikan dengan mengintegrasikannya dalam programprogram daerah sesuai acuan program pembangunan nasional.

Delapan tujuan MDG's yang telah dicapai, pada bidang kesehatan diantaranya pertama, menurunkan angka kematian anak terhitng dari tahun 1990 sampai 2015. Pada 2007, angka kematian anak sekitar 44 per 1.000 kelahiran hidup. MDGs menargetkan pengurangan angka kematian anak 2015 adalah 32 per 1.000 kelahiran hidup. Kedua, meningkatkan kesehatan ibu, sejak 1990 terjadi penurunan yaitu dari 390 menjadi sekitar 307 per 100.000 kelahiran hidup pada tahun 2000. Target MDGs 2015 adalah sekitar 110 per 100.000 kelahiran hidup. Untuk mencegah terjadinya kematian ibu, di antaranya adalah persalinan yang aman bagi ibu yaitu persalianan yang dibantu tenaga persalinan terlatih. Tahun 2007, proporsi persalinan yang dibantu tenaga persalinan terlatih adalah 73 persen. Ketiga, penanganan berbagai penyakit menular berbahaya yaitu HIV, TBC, malaria dan penyakit menular lainnya, prevalensi HIV-AIDS nasional saat ini adalah 5,6 per 100.000 orang. Namun, tidak ada indikasi laju penyebaran HIV-AIDS terhenti (Stalker, 2007). Derajat kesehatan masyarakat yang masih belum optimal pada hakikatnya dipengaruhi oleh kondisi lingkungan, perilaku masyarakat, pelayanan kesehatan dan genetika, hasil Riskesdas (2007), diketahui bahwa rumah tangga yang telah mempraktikkan perilaku hidup bersih dan sehat (PHBS) baru mencapai 38,7\%. Kementerian Kesehatan Tahun 2010-2014 mencantumkan target $70 \%$ rumah tangga sudah mempraktekkan (perilaku hidup bersih dan sehat) PHBS pada tahun 2014 (Kementerian Kesehatan RI, 2011)..
Berbagai upaya telah dilakukan oleh pemerintah, tapi belum sepenuhnya mencapai target MDGs baik secara general maupun khusus di bidang kesehatan. Masih banyak masyarakat yang belum tahu MDG's. Pemerintah melalui instansi terkaitnya dalam menjalanakan pencapaian program MDG's, kurang memanfaatkan kegiatankegiatan yang bersinggunngan terhadap pencapaian MDG's, seperti: praktik keperawatan komunitas yang dilakukan oleh instansi-instansi pendidikan keperawatan. Padahal perawat komunitas dalam memberikan asuhan kepada masyarakat, yaitu mengajarkan bagaimana upaya-upaya peningkatan kesehatan kepada masyarakat. Besar peran perawat komunitas perlu diapresiasi oleh pemerintah melalui dinas terkaitnya untuk di jadikan mitra dalam pencapaian MDG's, atau dapat diarahkan kepada pencapaian MDG's supaya apa yang akan dan telah dilakkukan dapat lebih focus kepada pencapaian target MDG's. Utamanya menjadikan masyarakat yang mandiri dan dapat menolong dirinya sendiri. Masyarakat sebagai warga Negara yang baik, sudah seharusnya turut mensukseskan apa yang menjadi tujuan pemerintah.

MDG's telah berakhir pada 2015, namun hingga kini belum ada konsep final yang akan meneruskan program MDG's. Untuk itu, ilmuwan dan berbagai kalangan berusaha mendalami konsep Suitanable Development Goals (SDG's) sebagai penerus MDG's.

SDG's pada prinsipnya meneruskan kegiatan MDG's dan merupakan perluasan dari MDG's sendiri dengan 17 sasaran yang salah satunya pula untuk mengurangi angka kematian ibu. Strategi yang diambil pemerintah untuk dijadikan solusi penyelesaian terhadap tingginya angka kematian ibu melahirkan adalah Perencanaan Persalinan dan Pencegahan Komplikasi (P4K) dengan stiker. Strategi ini ditetapkan pada tahun 2008 oleh Menteri Kesehatan Indonesia Dr.dr.Siti Fadilah Supari, Sp.JP(K). Berdasarkan Buku Pedoman $\mathrm{P} 4 \mathrm{~K}$, strategi $\mathrm{P} 4 \mathrm{~K}$ dengan stiker ini merupakan suatu kegiatan yang di fasilitasi oleh Bidan di desa/kelurahan dalam rangka membuat suami, 
SAKAI SAMBAYAN — Jurnal Pengabdian kepada Masyarakat

keluarga dan masyarakat ikut berperan aktif dalam merencanakan persalinan yang aman dan persiapan menghadapi komplikasi bagi ibu hamil, termasuk perencanaan penggunaan KB pasca persalinan dengan menggunakan stiker sebagai media notifikasi sasaran dalam rangka meningkatkan cakupan dan mutu pelayanan kesehatan bagi ibu dan bayi baru lahir. Tujuan P4K adalah untuk meningkatkan cakupan dan mutu pelayanan kesehatan bagi ibu hamil dan bayi baru lahir. Pelaksanaan strategi ini dilakukan pemeriksaan kehamilan oleh bidan atau tenaga kesehatan sebagai upaya untuk meningkatkan pengetahuan ibu hamil, suami dan keluarga, tentang :

1. Semua kehamilan berisiko dan membahayakan

2. Bahaya kehamilan dan persalinan

3. Ajakan kepada ibu hamil, suami dan keluarganya untuk melakukan perencanaan persalinan, yang meliputi :
a. Tempat persalinan
b. Penolong persalinan
c. Persiapan transportasi
d. Persiapan keuangan
e. Calon donor darah
f. Persiapan pakaian bayi dan ibu hamil
g. Perencanaan KB (Keluarga Berencana) setelah melahirkan

Dengan kata lain, strategi ini merupakan suatu upaya untuk meningkatkan kewaspadaan yang dilakukan sejak awal dalam menghadapi persalinan bagi ibu hamil. Tahap pelaksanaan strategi P4K pertama dilakukan di 9 provinsi yang memiliki jumlah penduduk terbanyak, yaitu Sumatera Utara, Sumatera Selatan, Lampung, DKI Jakarta, Banten, Jawa Barat, Jawa Tengah, Jawa Timur dan Sulawesi Selatan, yang nanti nya akan diikuti oleh provinsi yang lain (Sumber : http://m.news.viva.co.id/news/read/459389menkes--angka-kematian-ibu di indonesia--mariturunkan-segera diakses pada tanggal 8 Mei 2015 pukul 19:04 WIB).

Pulau Sumatra tersebar di 3 Provinsi, yaitu Sumatra Utara dengan jumlah penduduk laki-laki dan perempuan sebanyak 12.982.204 jiwa, kemudian Lampung dengan jumlah penduduk lakilaki dan perempuan sebanyak 7.608.405 jiwa dan Sumatra Selatan dengan jumlah penduduk laki-laki dan perempuan sebanyak 7.450.394 jiwa. Sehingga strategi P4K tahap pertama dilaksanakan di ketiga provinsi tersebut. AKI di Lampung pada tahun 2013 mencapai 359 per 100.000 kelahiran hidup. Humas Dinas Kesehatan Provinsi Lampung Asih Hendrastuti mengatakan penurunan AKI dapat dilakukan melalui P4K. (Sumber : http://lampost.co/berita/p4k-solusipenurunanangka-kematian-ibu-danbayidiakses pada tanggal 8 Mei 2015 pukul 18:32 WIB). Kota Bandar Lampung merupakan ibukota dari Provinsi Lampung yang dekat dengan pengawasan dari pemerintah kota maupun provinsi. Tetapi berdasarkan data tersebut Bandar Lampung justru menjadi kota/kabupaten dengan angka kematian ibu tertinggi di Provinsi Lampung. Padahal P4K sudah dilaksanakan sejak tahun 2010, terhitung kurang lebih sudah 3 tahun lamanya, akan tetapi angka kematian ibu belum menurun sesuai dengan target MDG's yaitu 102 per 100.000 kelahiran hidup.

Kecamatan Panjang merupakan kecamatan dengan tingkat kematian ibu melahirkan tertinggi di Kota Bandar Lampung, yaitu sebanyak 10 jiwa dari 4.723 kelahiran hidup dari tahun 2010 hingga 2013. Jika di ubah menjadi rasio kematian ibu menjadi 211 per 100.000 kelahiran hidup. Dengan Kelurahan Panjang Utara sebagai kelurahan dengan kasus kematian ibu tertinggi, sedangkan kelurahan lainnya yang ada di Kecamatan Panjang tidak mengalami kasus kematian ibu setinggi yang terjadi di Kelurahan Panjang Utara, seperti Kelurahan Pidada, Kelurahan Panjang Selatan, Kelurahan Karang Maritim, Kelurahan Srengsem serta Kelurahan Way Lunik, masing-masing hanya terdapat 1 kasus kematian ibu sepanjang tahun 2010-2013. Padahal program P4K dilaksanakan di seluruh kelurahan di Kota Bandar Lampung, tidak terkecuali di Kelurahan Panjang Utara. Penyebab kematian ibu di Kecamatan Panjang sebagian besar 
SAKAI SAMBAYAN — Jurnal Pengabdian kepada Masyarakat

dikarenakan oleh pendarahan, eklamasi (keracunan dalam kehamilan), anemia, syok sepsis encepalitis (syok dikarenakan infeksi di kepala dari dalam kandungan), TBC dan jantung. Bahkan ada beberapa ibu hamil yang meninggal dikarenakan melahirkan tidak ditolong oleh tenaga kesehatan setempat, seperti yang terjadi di Kelurahan Way Lunik dan Kelurahan Panjang Utara, Kecamatan Panjang. Terdapat beberapa kelahiran yang dilakukan di tempat yang tidak layak dan tanpa bantuan tenaga kesehatan. Kasus kematian ibu hamil yang terjadi di Kelurahan Way Lunik terjadi akibat ibu hamil melahirkan hanya dibantu oleh orang tuanya, sedangkan yang terjadi di Kelurahan Panjang Utara yaitu ibu hamil melahirkan sendiri tanpa bantuan tenaga kesehatan dan hal ini terjadi di kamar mandi rumah ibu tersebut.(Sumber : Dinas Kesehatan Bandar Lampung, 2013).

Strategi P4K dengan stiker ini bertujuan untuk memudahkan ibu hamil mempersiapkan persalinannya dengan mendata berbagai informasi yang diperlukan ibu hamil saat akan menghadapi persalinan, seperti tempat persalinan, penolong persalinan, persiapan transportasi, persiapan keuangan, dan calon donor darah sebagai upaya peningkatan pelayanan kesehatan ibu. Dengan pendataan yang cukup lengkap seperti itu seharusnya tidak terjadi kasus ibu hamil melahirkan di rumah sendiri tanpa bantuan tenaga kesehatan. Selain itu, pada awal dilaksanakannya P4K dengan stiker pada tahun 2010 angka kematian ibu di Kecamatan Panjang sejumlah 4 orang kemudian turun menjadi 0 di tahun 2011, tetapi kemudian naik menjadi 2 orang pada tahun 2012 dan pada tahun 2013 naik kembali menjadi 4 orang. Adanya strategi ini diharapkan akan menurunkan angka kematian ibu, tetapi di Kecamatan Panjang menunjukkan setelah pelaksanaan strategi P4K dengan stiker angka kematian ibu justru kembali meningkat. Strategi yang dikelola dengan baik seharusnya dapat membantu suatu organisasi mencapai tujuan atau sasaran yang diinginkan. Seperti yang dikemukakan oleh Pearce dan Robinson (1997:20) yang mendefinisikan manajemen strategi sebagai suatu keputusan yang menghasilkan formulasi dan implementasi perencanaan untuk mencapai sasaran-sasaran dalam organisasi.

Dari pengertian dan kasus tersebut hendaknya strategi yang telah dibuat harus dapat dilaksanakan dengan baik dengan memperhatikan berbagai hal yang memengauhinya. Sehingga diperlukanlah suatu proses lainnya yaitu implementasi atau pelaksanaan strategi. Salusu (2006: 409) mengatakan bahwa implementasi strategi adalah seperangkat kegiatan yang dilakukan menyusul suatu keputusan. Suatu keputusan selalu dimaksudkan untuk mencapai sasaran tertentu. Merealisasikan pencapaian sasaran diperlukan serangkaian aktivitas. Implementasi adalah operasionalisasi dari berbagai aktivitas guna mencapai suatu sasaran tertentu.

\section{Bahan dan Metode}

Sebagaimana diuraikan di atas bahwa permasalahan yang ada adalah mengenai peningkatan kapasitas sasaran pelaksana P4K di Puskesmas Kecamatan Panjang Kota Bandar Lampung, maka untuk memecahkan permasalahan tersebut diadakan kegiatan seminar tentang implementasi strategi P4K untuk mengurangi AKI, dengan rangkaian kegiatan sebagai berikut:

1. Penyampaian materi oleh fasilitator disertai kesempatan tanya jawab.

2. Diskusi kelompok, berguna untuk membahas persoalan-persoalan yang dihadapi dikaitkan dengan materi yang sedang dipelajari.

Evaluasi dalam kegiatan pelatihan ini dibedakan menjadi dua macam, yaitu:

a. Evaluasi Perubahan Pengetahuan

Evaluasi ini dilakukan dengan pre test dan post test. Selisih antara post test dan pre test dinyatakan dalam persen. Pertambahan tersebut kemudian dikelompokan dalam strata buruk, sedang dan baik.

b. Evaluasi Dampak

Evaluasi ini dilakukan sebelum kegiatan seminar berakhir Mekanismenya dengan 
SAKAI SAMBAYAN — Jurnal Pengabdian kepada Masyarakat

membagikan kuesioner kepada sasaran pelaksana P4K dan dihitung.

Dalam pelaksanaan seminar akan menggunakan metode ceramah dan diskusi. Metode ceramah dan diskusi di dalam ruangan yang digunakan untuk menyajikan materi. Adapun materi yang akan diberikan adalah wawasan tentang strategi, manajemen strategi, manfaat dan tujuan manajemen strategi, model manajemen strategi serta implementasi dan isu-isu yang memengaruhinya.

\section{Hasil dan Pembahasan}

Secara umum diperoleh gambaran bahwa kegiatan Peningkatan Kapasitas Sasaran Pelaksana Program Perencana Persalinan Dan Pencegahan Komplikasi (P4K) Dalam Pelaksanaan Strategi Untuk Mengurangi Angka Kematian Ibu (AKI) Menuju Sustainable Development (Pembangunan Berkelanjutan) Di Kecamatan Panjang Kota Bandarlampung yang telah dilakukan, telah membawa peningkatan kemampuan dasar peserta. Peningkatan terendah sebesar $10 \%$ dan peningkatan tertinggi sebesar $20 \%$. Rata-rata peningkatan adalah sebesar $14,8 \%$.

Peserta yang nilai dasarnya (pre test) cukup tinggi (sekitar 7 peserta) dengan kisaran nilai mulai dari 60-70, ternyata hasil post testnya pun menunjukkan peningkatan yang cukup signifikan. Setelah diurai oleh tim pengabdian, didapati bahwa hasil Pre-test peserta dengan hasil post test peserta yang terkategori tinggi memiliki korelasi dengan tingkat pendidikan dan pengalaman kerja. Oleh karena itu melalui kegiatan ini, peserta telah mendapatkan pemahaman yang utuh tentang pelaksanaan strategi di lapangan untuk mengurangi angka kematian ibu sehingga dapat mewujudkan pembangunan yang berkelanjutan.

\section{Kesimpulan}

Berdasarkan hasil dan evaluasi pelaksanaan pengabdian kepada masyarakat dapat disimpulkan beberapa hal sebagai berikut:

1. Kemampuan peserta pelatihan pada aspek kognetif dan afektif mengalami peningkatan dengan rata-rata sebesar $14,8 \%$.

2. Hasil evaluasi menunjukan peserta memiliki persepsi positif dan motivasi yang tinggi untuk menjalankan point penting dalam pelatihan untuk membenahi metode dan proses pelaksanaan strategi untuk mengurangi angka kematian ibu.

3. Peserta menghendaki adanya pelatihan lanjutan.

\section{Ucapan Terima Kasih}

Ucapan terimakasih terutama kepada Universitas Lampung yang telah memberikan dana kegiatan pengabdian BLU Senior tahun 2017 dan segenap pihak yang membantu dalam mensukseskan kegiatan ini dari pembuatan proposal yaitu tim pengabdian dan beberapa mahasiswa bimbingan untuk turut berpartisipasi dalam kegiatan ini serta pihak Puskesmas Kecamatan Panjang yang menjadi sasaran kegiatan.

\section{Daftar Pustaka}

Dinas Kesehatan Kota Bandar Lampung.

http://www.lampost.co

http://www.m.news.viva.co.id

Impres Nomor 3 Tahun 2010 Tentang Program Pembangunan Berkeadilan

indonesiadata.co.id

kemenkes.go id

Pearce, dan Robinson. 1997. Manajemen Strategi: Formulasi, Implementasi, dan pengendalian (jilid satu). Binarupa Aksara. Jakarta.

sekretariatmdg.or.id 